\title{
Effect of Salt Stresses on Seed Germination and Early Seedling Growth of Camelina sativa $\mathrm{L}$.
}

\author{
Gebremedhn Yohannes $^{1 *}$, Leul Kidane ${ }^{2}$, Berhanu Abraha ${ }^{3}$ and Tadesse Beyene ${ }^{2}$ \\ ${ }^{1}$ Department of Biology, College of Natural and Computational Science, P. O. Box 667, \\ Wachemo University, Hossana, Ethiopia (*gebrey21@gmail.com). \\ ${ }^{2}$ Department of Biology, College of Natural and Computational Science, P. O. Box 231, Mekelle \\ University, Mekelle, Ethiopia. \\ ${ }^{3}$ Department of Biology, College of Science, Bahir Dar University, Bahir Dar, Ethiopia.
}

\begin{abstract}
Camelina sativa is a promising low-input, high yielding biodiesel crop that can be suitable to grow on marginal lands and is a good source of omega-3 fatty acids. But, saltiness is an overall issue of agriculture that constrains the germination, development and productivity of plant because of osmotic and ionic poisonous quality impacts. The aim of this study was to assess the effect of salinity $(\mathrm{NaCl}$ and $\mathrm{KCl})$ on germination and early seedling growth of Camelina sativa. Camelina sativa seeds were obtained from agricultural research sector of Wachemo University. In the laboratory, six salinity levels of $\mathrm{NaCl}$ and $\mathrm{KCl}(0,1,2,3,4$ and $5 \mathrm{~g} / \mathrm{L})$ were prepared and arranged in completely randomized design with four replications. The result of the study revealed that $C$. sativa seedlings were differ significantly $(\mathrm{p}<0.05)$ on speed of germination, germination percentage, germination index, shoot length, root length, vigor index, root shoot ratio and seedling fresh weight, relative injury rates of $\mathrm{NaCl}$ and $\mathrm{KCl}$, shoot height reduction and root height reduction. However, there is no significant effect between salt type versus salinity level and salt type in all parameters tested except shoot length and shoot height reduction at $5 \%$ significant level. The increase in both salts $(\mathrm{NaCl}$ and $\mathrm{KCl})$ concentration in culture medium causes a significant decreases in speed of germination, germination percentage, germination index, shoot length, root length, vigor index, root shoot ratio and seedling fresh weight of the salt treated $C$. sativa seeds as compared with the control (C. sativa seeds watered with distilled water). Similarly, relative injury rates $\mathrm{NaCl}$ and $\mathrm{KCl}$ shoot height reduction, root height reduction were highly increased as salinity level increases. Generally, as the concentration of $\mathrm{NaCl}$ and $\mathrm{KCl}$ was increased the overall germination and early seedling performance of $C$. sativa decreased. The effect of salinity on physiology, molecular and biochemical of properties of C. sativa should be studied.
\end{abstract}

Keywords: Camelina sativa, Salinity effect, $\mathrm{NaCl}, \mathrm{KCl}$, Seed germination, Seedling growth.

\section{INTRODUCTION}

Salinity is one of the major abiotic issuesof worldwide problems that limit plant growth and productivity in many regions of the world; due to increasing use of poor quality of water for irrigation and soil salinization (Khodarahmpour et al., 2012; Zhang and Shi, 2013).This problem is particularly serious in arid and semi-arid regions of the world (Khan et al., 1999). Salinity causes not only differences between the mean yield and the potential yield, but also causes yield 
reduction from year to year. It affects the plant growth directly through its interaction with metabolic rates and pathways within the plants. It affects plant growth at all stages of development and sensitivity to salinity varies from one grow the stage to another. Adverse effects of salt stress on germination, seedling growth as well as some physiological activities of a number of cultivated plant species have been extensively investigated (Hussain et al., 2008).

One of the most detrimental effects of salinity is the accumulation of $\mathrm{Na}^{+}$and $\mathrm{Cl}^{-}$ions in tissues of plants subjected to soils with high concentrations of $\mathrm{NaCl}$ (Xue et al., 2014). High concentration of $\mathrm{Na}^{+}$inhibits uptake of $\mathrm{K}^{+}$which is an essential macronutrient for plants growth and development that results in low productivity and may even cause death (Wu et al. 2015). Plants have developed various physiological and biochemical mechanisms to maintain a relatively stable intracellular environment via accumulating various solutes under saline condition (Roy et al., 2014). The osmotic adjustment in plants can maintain the uptake of water and the turgor of cell, allowing regular physiological metabolisms (Radić et al., 2013). Proline, as an important osmoprotectants, contributes to osmotic adjustment, protecting enzymes from oxidative damage under saline condition (Ashraf and Harris, 2004). In addition, under saline condition, the accumulation of other compounds such as soluble sugar, which at higher temperatures are non-toxic to cytoplasmic functions, allowing turgor maintenance and/or protection of macromolecular structure against the destabilizing effects of the decrease in water activity, has also been reported in many plants species (Wu et al., 2015).

Camelina sativa (L.) Crantz, Brassicaceae (false flax/gold-of-pleasure) is herbaceous and an annual crop. It grows up to aheights of $90 \mathrm{~cm}$ tall and has branched stems that become woody at maturity. Leaves are arrow-shaped, sharp-pointed, 5 to $8 \mathrm{~cm}$ long with smooth edges. It produces prolific small, pale yellow or greenish-yellow flowers with 4 petals. Seed pods are 6 to $14 \mathrm{~mm}$ long and superficially resemble the bolls of flax. Seeds are small $(0.7 \mathrm{~mm} \times 1.5 \mathrm{~mm})$, pale yellow-brown, oblong and rough, with a ridged surface (Francis and Warwick, 2009). It is originated in the Mediterranean to central Asia/ east European and has been utilized since the late Neolithic Era when it was domesticated in southeast Europe. During the Iron Age, cultivation of Camelina was confirmed from west Asia throughout the European continent and northward to Scandinavia (Larsson, 2013). The interest in Camelina has been revived due to an increased need for both food and biofuel oils, and pilot-scale productions have been established in European countries as well as in North America (Dönmez and Belli, 2007). 
Many research reports suggest that $C$. sativa as one of the most cost-effective oilseed crop to produce essential fatty acids, particularly omega-3 fatty acids (Al-Shehbaz et al., 2006; Moser and Vaughn, 2010; Waraich et al., 2013). The nutritional deficiency can be alleviated by the addition of omega-3fatty acid rich oils in the diet. In such a situation $C$. sativa oil can be an excellent source of poly-unsaturated fatty acids and omega-3 fatty acid in particular. C. sativa seeds are good source of these ingredients, which include omega-3 fatty acids, carbohydrates, proteins, minerals and vitamins (Berti et al., 2016). The consumption of foods high in omega 3 fatty acids helps to fight inflammation, heart disease prevention and brain health (Eidhin and O'Beirne, 2010). Karvonen et al. (2002) reported that oil of $C$. sativa is commendable in lowering serum cholesterol of people with hypercholestrolemic.

Camelina oil meal can be used as a protein rich source in poultry diets. When Camelina oil mixed with chicken feeds, it increases the omega-3 content of the eggs without any displeasing its flavor. The same to that when $C$. sativa seed and meal are used in the diets of dairy cows, it reduces milk fat with softer, more spreadable butter mainly due to unsaturated fatty acids in the feed (Hurtaud and Peyraud, 2007). Sokolinska et al. (2011) found that feeding of sheep with C.sativa cover results in significant changes in aroma and content of volatile compounds in collected milk.

C. sativa also has a medicinal value. Ni Eidhin et al. (2003); and Lu and Kang (2008) determined cholesterol reducing effect of $C$. sativa oil in a test with slightly and moderately hypercholesterolemic subjects. The consumption of food high in omega 3 fatty acids helps to fight inflammation, heart disease prevention and brain health (Eidhin and O'Beirne, 2010).

Besides, C.sativa is a good source of biodiesel/fuel production. The biodiesel produced from this plant is low cost renewable fuel, has recently attracted great attention as one of the more important alternatives for petro-diesel fuel. Biodegradability, lower sulfur and aromatic content, derivation from renewable and waste feedstock, higher cetane number and less emission of carbon monoxide are the main advantages of biodiesel (Yang et al., 2016).

C. sativa is a recently introducing oilseed crop to Ethiopia and has potential for large scale production for the biofuel market. It is a promising and sustainable alternative energy crop (Al-Shehbaz et al., 2006). Camelina sativa oil contains around $40 \%$ fatty acids, of which only a small percentage are saturated. Camelina sativa derived bio-kerosene used in air travel has shown $84 \%$ reduction in greenhouse gas emissions during its life cycle, compared to petroleum 
kerosene. It has the potential of becoming the renewable fuel of choice for air navigation in the future. Interest in C. sativa has recently been revived because of its exceptional level of omega-3 essential fatty acids and its favorable agronomic characteristics (Fro“hlich and Rice, 2005). Oil extracted from C. sativa seeds have high ratio of fatty acids rich in Omega-3 ( $40 \%$ volume of total fatty acids)and this Omega-3 is more stable than omega-3 obtained from fish. Therefore, it could be used for human food consumption (Waraich et al., 2013). It uses in dressings and mixed with vinegar; with the resulting mixtures being stable for many months at room temperature as its resistance to oxidation (Waraich et al., 2013). The essential omega-3 fatty acid is important to secure the balanced food in Ethiopia.Generally, it is important for the green and sustainable development Ethiopia. The bio-kerosene produced from Camelina sativa is used in air travel having the ability of reducing greenhouse gas emissions.It helps in the implementation of climate-resilient Green Economy Strategy, with the goal of enabling fast economic growth that ensures environmental safety. Additionally, it uses good raw material for theagro-industries and to achieve the second growth and transformation plan in Ethiopia.

Even though $C$. sativa have those curtail economic importance, but there is no information available regarding salinity stress tolerance rates this oil crop in Ethiopia. In Ethiopia, approximately 11 million hectare land is salt affected in semi-arid and arid regions of the country (Fantaw Abegaz, 2007). According to Tamirie Hawando (1994), salt-affected flats have increased from $6 \%$ to $16 \%$ of the total land area of Ethiopia in last years of the $20^{\text {th }}$ century and $9 \%$ of the population lived in these areas. About 44 million hectares (36\% of the country's total land areas) are potentially susceptible to salinity problems. These problems of salt affected soils are old, but their magnitude and intensity have been increasing fast due to the establishment of large-scale irrigated farms in recent decades; inadequate delivery of drainage system and poor water management practices coupled with unreliable reclamation procedures have made the problem worse, as reclaiming back these salt affected areas and use them for agricultural production is very costly and time consuming. The development of salt tolerant crops like $C$. sativa is important to seek the food security of the rapidly growing population. Identification of species capable of growing on saline habitats is a good way of using such unproductive lands. The present work is a step forward in this direction. This study could be a starting point in regenerating salinity research baselines and expansion of $C$. sativa and other mustard growing areas of the country.In countries like Ethiopia that introducing $C$. sativa for biofuel as sustainable 
alternative energy and human food consumption is important. It could also help for further introduction of resilient species as a very urgent requirement to salinity affected areas and develop high yielding varieties.Therefore, the objective of this study isto investigate the effect of salinity on germination and early seedling growth of $C$. sativa.

\section{MATERIALS AND METHODS}

\subsection{Description of the Study Area}

This study was conducted in 2018 at Wachemo University (main campus). Wachemo University is found in Hadiya zone. Hadiya is one of the SNNPR zone in the Federal Democratic Republic of Ethiopia. It is located at $7^{0} 07^{\prime}-7.92^{\prime} \mathrm{N}$ and $37^{\circ} 29^{\prime}-38^{0} 13^{\prime} \mathrm{E}$. It is laid on an altitude of 5013000 meters above the mean sea level. The mean annual temperature of Hadiya zone ranges from $12.6-27.5^{\circ} \mathrm{C}$, and the amount of rainfall received ranges from $801 \mathrm{~mm}$ to $1400 \mathrm{~mm}$.

\subsection{Experimental Set Up}

The experimentwas carried out from May 2018- July 2018 in the laboratory of Biology department, Wachemo University. The seeds of C. sativawere collected from Wachemo University agricultural research sector.Before the beginning of the experiment solutions were made by dissolving sodium chloride $(\mathrm{NaCl})$ and potassium chloride $(\mathrm{KCl})$ separately in distilled water at five different concentration levels and wereleft for 36hours forcomplete dissolution. The salt solutions were prepared every 3 days to keep them relatively fresh for the germinating seeds. Different concentrations of $\mathrm{NaCl}$ and $\mathrm{KCl}$ were prepared separately by dissolving $1 \mathrm{~g} / \mathrm{l}, 2 \mathrm{~g} / \mathrm{l}, 3 \mathrm{~g} / \mathrm{l}$, $4 \mathrm{~g} / \mathrm{l}, 5 \mathrm{~g} / \mathrm{l}$ and distilled water as control (Gebremedhin and Berhanu, 2013).

Subsequently during solution preparation, petridishes were washed and sterilized with alcohol and was air dried for eight hours. Germination compartments were prepared from the sterilized petridishes and filter papers (Whatman \# 2) and were labeled for salt types $(\mathrm{NaCl}$ and $\mathrm{KCl}$ ) and concentrations of salt solutions.

Next the preparation of the germination compartments, treatments were arranged in a completely randomized design (CRD) consisting of two factors and four replications. The first factors were the two salt types $(\mathrm{NaCl}$ and $\mathrm{KCl})$, the second and main factor comprised five salt concentrations of $\mathrm{NaCl}$ and $\mathrm{KCl}$ i.e., 0 (control), $1 \mathrm{~g} / 1,2 \mathrm{~g} / \mathrm{l}, 3 \mathrm{~g} / \mathrm{l}, 4 \mathrm{~g} / \mathrm{l}, 5 \mathrm{~g} / \mathrm{l}$.

Seeds were surface sterilized with 5\% sodium hypochlorite solution for 5 minutes, and were rinsed 3 times with distilled water. Forty (40) uniform sized and healthy seeds were sown 
in each leveled Whatman paper covered petridishes. Each germination compartment was irrigated with $15 \mathrm{ml}$ of the prepared salt solutions at constant interval of 24 hours. Counting of germinated seeds was startedon the third day of sowing of the seeds in each chamber. Seeds were considered to be germinated when the plumule emerge $2 \mathrm{~mm}$ through the seed coat (Panuccio et al., 2014). The number of seeds germinated was recorded daily for 11 days from each treatment.

After 11 days, seedlings were harvested.Earlyseedling growth parameters such as root and shoot lengths of twenty sample seedlings were measured. Root and shoot freshweight before oven dryingand root and shoot dry weight after oven drying from twenty seedling samples were measured and recorded to assess the effects of salinity on early seedling attributes of $C$. sativa.

\subsection{Parameters Studied To Examine the Effect of Salinity}

\subsubsection{Germination Percentage (GP \%):}

$\mathrm{GP} \%=\frac{\text { Number of germinated seeds }}{\text { Total number of seeds tested }} \times 100$ (Kandil et al., 2012).

\subsubsection{Speed of Germination (SG):}

Number of seedlings emerging daily was counted from day of planting till the last day of germination and cumulative index was made tocompute the speed of germination as shown below.

$$
\text { Speed of germination }=\frac{\mathrm{N} 1}{1}+\frac{\mathrm{N} 2}{2}+\cdots+\frac{\mathrm{Nx}}{\mathrm{x}}(\text { Panuccio et al. }, 2014)
$$

Where, N1-- $\mathrm{N}_{\mathrm{x}}$ are the number of seeds germinated on day 1 to day $\mathrm{x} ; 1--\mathrm{x}$ are the number of days.

\subsubsection{Germination index (GI):}

Calculated as the product of number of days after sowing and number of germinated seeds divided to the total number of sown seeds.

GI $=\frac{\sum \text { diNi }}{S}$ (Panuccio et al., 2014), where (di) number of days after sowing of seeds under a particular treatment, $(\mathrm{Ni})$ number of germinated seeds , (S) total number of seeds that were sown.

\subsubsection{Vigor index (VI):}

Is the ability of the crops to survive, grow and flourish under the salt stressed condition and was calculated as (Kandil et al., 2012).

$V I=\frac{[\text { Germination Percentage }(\%) \times \text { SeedlingLength }(\mathrm{cm})]}{100}$

Root length and Shoot length of thesampled seedlings were measured and recorded in centimeter $(\mathrm{cm})$ using a ruler during the harvest time after 11days of subsequent observations. 
Root fresh weightand shoot fresh weights of the germinated seeds of the twentyseedlingswasmeasured in grams before oven dry to evaluate the salt tolerance capacity of seeds that wasgerminated under different salt condition. Root dry weight and shoot dry weight of the germinated seeds $C$. sativa were measured in grams after oven drying and were calculated and recordedto evaluate the salt tolerance capacity of seeds that wasgerminated under different salt condition.

\subsubsection{Seedling height reduction (SHR):}

After 11 days of seedling growth, the delay in root length and shoot length was calculated and expressed in percentage by comparing the seedlings height grown at different salt conditions with the seedlings height grown at the control one.

$$
\text { SHR }=\frac{\text { Plant height at control-plant height at salt treat condition }}{\text { Plant height at control }} x 100 \text { (Islam and Karim, 2010). }
$$

Relative injury rates (RIR) of $\mathrm{NaCland} \mathrm{KCl}$ was calculated as the difference between germination percentage in control and germination percentage in salt treated seeds dividing by the germination percentage in the untreated seeds.

$$
\mathrm{RIR}=\frac{\mathrm{GP} \%(\text { control })-\mathrm{GP} \% \text { at salt treat condition }}{\mathrm{GP} \% \text { at control }} x 100
$$

The emergence of radicle (root) and shoot of each petri dish was assessed.

\subsection{Data Analysis}

The obtained data were examined by two-way analysis of variance (ANOVA) using statistical software (SPSS 20.0). Tukey's honest significance test was performed to determine significant difference between means at a significance level of $P \leq 0.05$.

\section{RESULTS AND DISCUSSION}

\subsection{Effect of Salinity on Seed Germination of Camelina sativa}

Investigation of variance revealed that both salinities $(\mathrm{NaCl}$ and $\mathrm{KCl})$ had significant effects on the studied parameters at 5\% significant level (Table 1). However, there is no significant $(\mathrm{P}<0.05)$ difference between the two salt types $(\mathrm{NaCl}$ and $\mathrm{KCl})$ and the interaction of salt concentration and salt type in all parameters tested except shoot length and root length (Table 1). The increase in salts stress in culture medium causes a significant decreases in speed of germination, germination percentage, germination index (Table 2), relative injury rates $\mathrm{NaCl}$ and $\mathrm{KCl}$ (Table 2), shoot length (Fig 1a), root length (Fig 1b), vigor index (Fig 3a), root shoot ratio 
(Fig 3b), shoot height reduction (Fig 2a), root height reduction (Fig 2b) and seedling fresh weight (Fig 3) of the salt treated $C$. sativa seeds as compared with the control (C. sativa seeds watered with distilled water).

Table 1. Analysis of variance for seed germination and early seedling growth of Camelina sativa germinated under different salinity levels of $\mathrm{NaCl}$ and $\mathrm{KCl}$.

\begin{tabular}{|c|c|c|c|c|c|c|c|c|c|c|c|}
\hline Source & $T G(\%)$ & $R I R$ & $S P$ & $G I$ & $S L$ & $R L$ & $R: S$ & VI & SHR & $F W$ & RHR \\
\hline $\begin{array}{l}\text { Salinity } \\
\text { Level }\end{array}$ & $6393.34 *$ & $6921.77 *$ & $1983.32 *$ & $2275.41 *$ & $11.17 *$ & $77.52 *$ & $9.00 *$ & $1370786.22 *$ & $10055.72 *$ & $0.19 *$ & $11020.65^{*}$ \\
\hline Salt Type & 145.26 & 158.56 & 54.74 & 49.61 & 0.042 & 0.356 & 1.82 & 7.06 & 41.72 & 0.0001 & 153.99 \\
\hline \begin{tabular}{|l|} 
Salinity \\
Level * \\
Salt Type \\
\end{tabular} & 120.82 & 130.48 & 26.66 & 36.43 & $0.199 *$ & 0.156 & 2.52 & 2860.51 & $160.28 *$ & 0.00001 & 87.52 \\
\hline \begin{tabular}{|l|} 
Error \\
\end{tabular} & 55.16 & 56.95 & 21.39 & 20.94 & 0.062 & 1.78 & 1.97 & 18021.43 & 48.59 & 0.021 & 197.18 \\
\hline
\end{tabular}

Note: *Significant at 0.05 according to Post Hoc LSD test. $\mathrm{TG}(\%)=$ Total Germination Percentage; RIR=Relative Injury Rate; GI=Germination index;

$\mathrm{SP} \quad=$ Speed of Germination; $\quad \mathrm{SL}=$ Seedling Length; $\quad \mathrm{RL}=$ Root Length;

SHR = Shoot Height Reduction; $\quad$ R:S = Root Shoot Ratio; VI = Vigor Index;

RHR = Root Height Reduction; $\quad$ FW $=$ fresh weight $\quad *$ Significant

Table 2. Effect of salinity $(\mathrm{NaCl} \& \mathrm{KCl})$ on speed of germination and seed germination percentage.

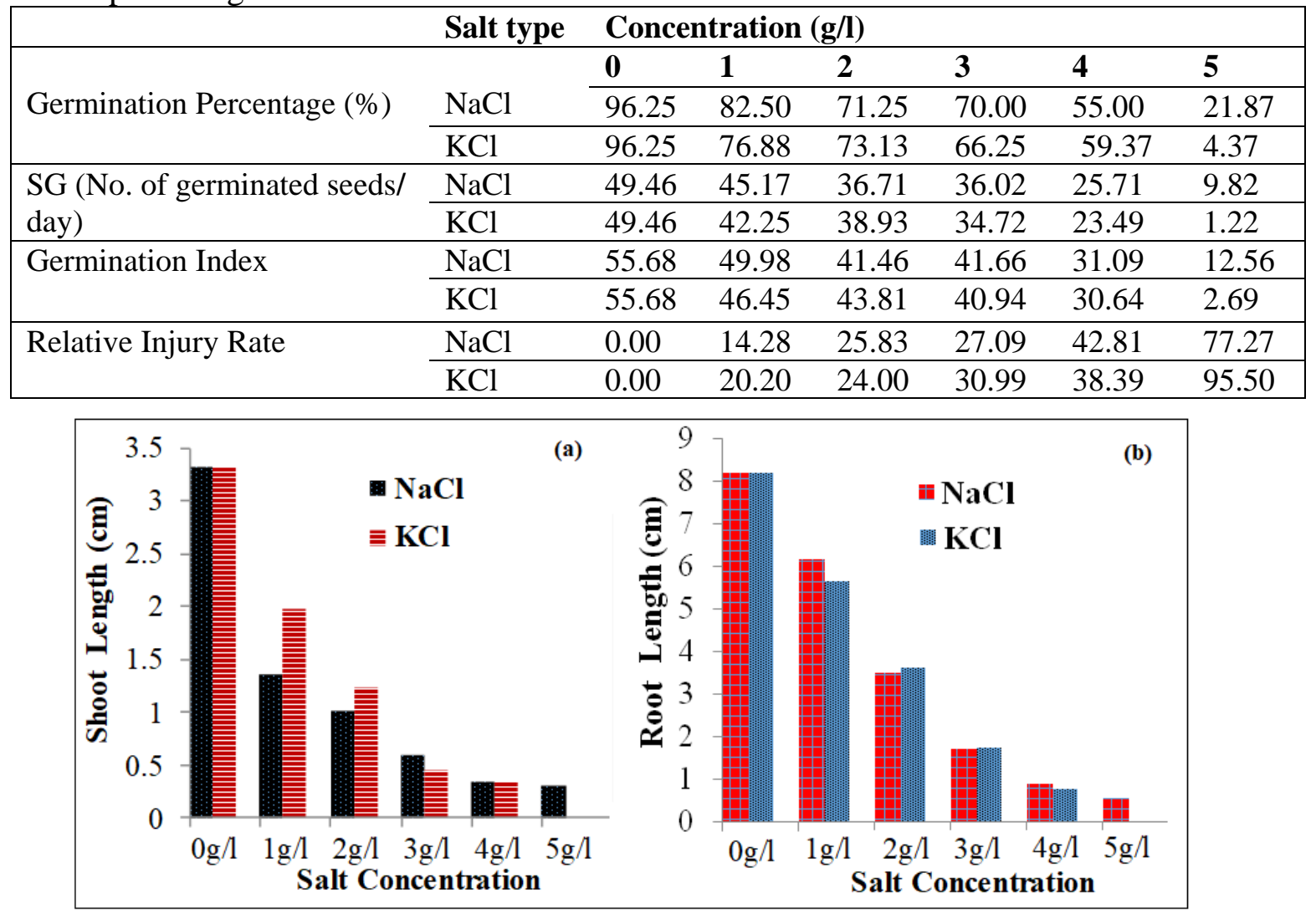

Figure 1. The Effect of salinity ( $\mathrm{NaCl}$ and $\mathrm{KCl})$ on shoot length (a) and root length (b). 


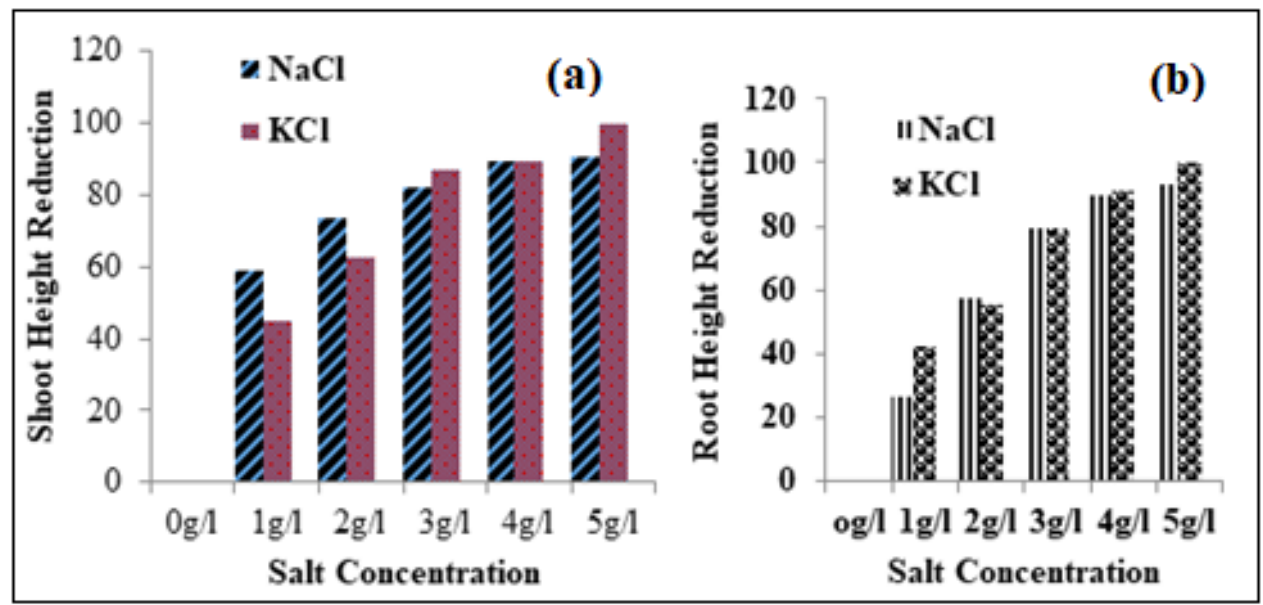

Figure 2. The Effect of salinity $(\mathrm{NaCl}$ and $\mathrm{KCl})$ on shoot height reduction (a) and root height reduction (b) of $C$. sativa.

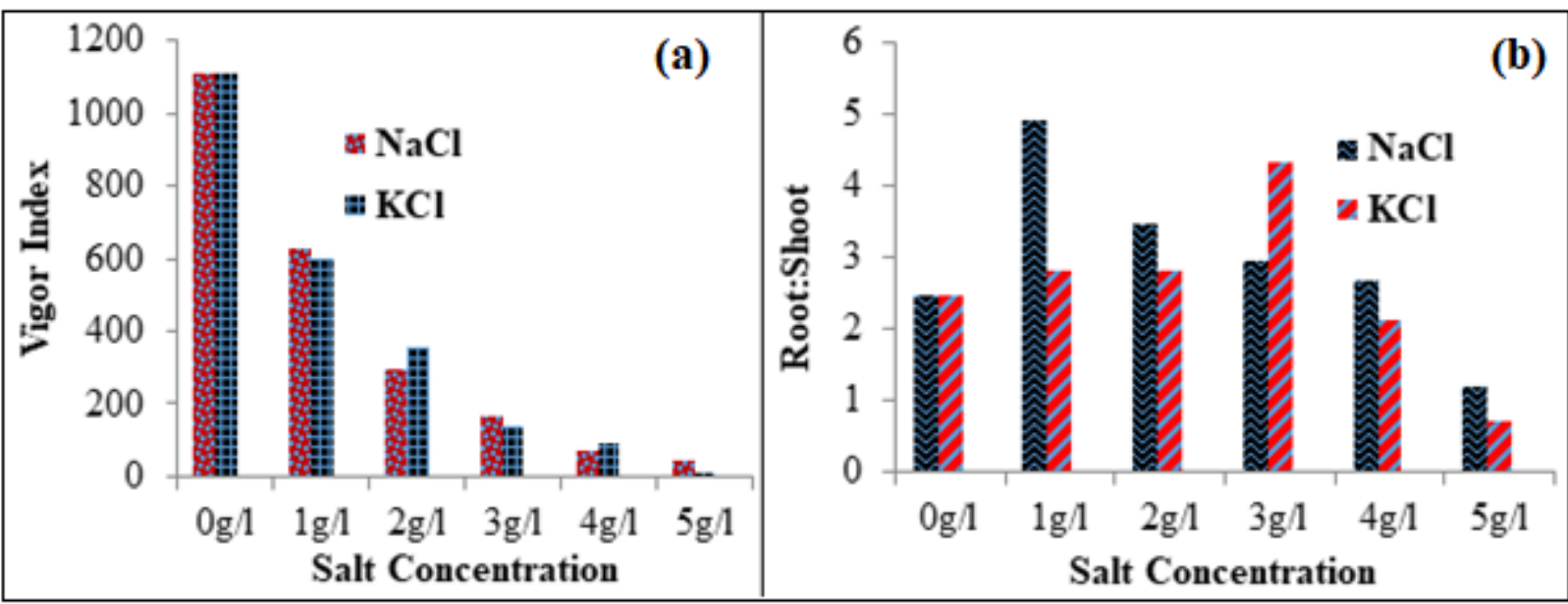

Figure 3. The Effect of salinity $(\mathrm{NaCl}$ and $\mathrm{KCl})$ on vigor index (a) and root shoot ratio (b).

\subsection{Total Germination Percentage and Speed of Germination}

Figures $1 \mathrm{a}$ and $1 \mathrm{~b}$ shows that increasing sodium chloride and potassium chloride concentrations were significantly $(\mathrm{P}<0.05)$ decreased the speed of germination and total germination percentage of $C$. sativa. The speed of germination was reduced from 49.46 to 5.52 as the salinity level of $\mathrm{NaCl}$ and $\mathrm{KCl}$ increased from $0 \mathrm{~g} / \mathrm{L}$ to $5 \mathrm{~g} / \mathrm{L}$ (Table 2). Similarly, the data in table 3 indicated total germination percentage reduced from $96.13 \%$ to $13.13 \%$ due to an increase in salinity level from $0 \mathrm{~g} / \mathrm{L}$ to $5 \mathrm{~g} / \mathrm{L}$. 
Table 3. Mean comparison of the traits under different salinity levels after 11 days of germination time.

\begin{tabular}{|llllllllllll|}
\hline $\begin{array}{l}\text { Salinity } \\
(\boldsymbol{g} / \boldsymbol{L})\end{array}$ & $\boldsymbol{G P}(\boldsymbol{\%})$ & $\begin{array}{l}\boldsymbol{R} \boldsymbol{R} \\
(\boldsymbol{\%})\end{array}$ & $\boldsymbol{S G}$ & $\boldsymbol{G I}$ & $\boldsymbol{S L}$ & $\boldsymbol{R L}$ & $\boldsymbol{R}: \boldsymbol{S}$ & $\boldsymbol{V I}$ & $\begin{array}{l}\boldsymbol{S H R} \\
(\boldsymbol{\%})\end{array}$ & $\begin{array}{l}\boldsymbol{R} \boldsymbol{R} \boldsymbol{R} \\
(\boldsymbol{\%})\end{array}$ & $\boldsymbol{F W}$ \\
\hline $\mathbf{0}$ & $96.13^{\mathrm{a}}$ & $0.00^{\mathrm{g}}$ & $49.46^{\mathrm{a}}$ & $55.68^{\mathrm{g}}$ & $3.32^{\mathrm{n}}$ & $8.19^{\mathrm{a}}$ & $2.47^{\mathrm{a}}$ & $1106.42^{\mathrm{a}}$ & $0.00^{\mathrm{f}}$ & $0.00014^{\mathrm{k}}$ & $0.392^{\mathrm{a}}$ \\
\hline $\mathbf{1}$ & $79.69^{\mathrm{b}}$ & $17.24^{\mathrm{h}}$ & $43.71^{\mathrm{b}}$ & $48.21^{\mathrm{h}}$ & $1.67^{\mathrm{p}}$ & $5.89 \mathrm{~b}$ & $3.86^{\mathrm{ab}}$ & $613.96^{\mathrm{b}}$ & $51.96^{\mathrm{g}}$ & $34.24^{\mathrm{l}}$ & $0.035^{\mathrm{b}}$ \\
\hline $\mathbf{2}$ & $72.19^{\mathrm{bc}}$ & $24.92^{\mathrm{i}}$ & $37.82^{\mathrm{c}}$ & $42.63^{\mathrm{i}}$ & $1.12^{\mathrm{q}}$ & $3.55^{\mathrm{c}}$ & $3.14^{\mathrm{bc}}$ & $323.1^{\mathrm{c}}$ & $68.06^{\mathrm{h}}$ & $56.04^{\mathrm{m}}$ & $0.022^{\mathrm{b}}$ \\
\hline $\mathbf{3}$ & $68.13^{\mathrm{cd}}$ & $29.04^{\mathrm{ij}}$ & $35.37^{\mathrm{cd}}$ & $41.30^{\mathrm{ij}}$ & $0.52^{\mathrm{r}}$ & $1.71^{\mathrm{d}}$ & $3.65^{\mathrm{cd}}$ & $152.56^{\mathrm{c}}$ & $84.22^{\mathrm{i}}$ & $79.19^{\mathrm{n}}$ & $0.014^{\mathrm{b}}$ \\
\hline $\mathbf{4}$ & $57.19^{\mathrm{e}}$ & $40.6^{\mathrm{k}}$ & $24.60^{\mathrm{e}}$ & $30.87^{\mathrm{k}}$ & $0.35^{\mathrm{rs}}$ & $0.81^{\mathrm{de}}$ & $2.4 \mathrm{~d}^{\mathrm{e}}$ & $78.38^{\mathrm{c}}$ & $89.47^{\mathrm{ij}}$ & $90.13^{\mathrm{np}}$ & $0.005^{\mathrm{b}}$ \\
\hline $\mathbf{5}$ & $13.13^{\mathrm{f}}$ & $86.39^{\mathrm{m}}$ & $5.52^{\mathrm{f}}$ & $7.631^{\mathrm{m}}$ & $0.16^{\mathrm{st}}$ & $0.28^{\mathrm{ef}}$ & $0.96^{\mathrm{ef}}$ & $21.63^{\mathrm{c}}$ & $95.21^{\mathrm{j}}$ & $96.54^{\mathrm{pq}}$ & $0.002^{\mathrm{b}}$ \\
\hline
\end{tabular}

Note:

*Mean with the same letters in each column are not significantly different at 0.05 as per LSD test. $\mathrm{GP}(\%)=$ Total Germination Percentage; RIR = Relative Injury Rate; GI = Germination index;

$\mathrm{SG} \quad=$ Speed of Germination; $\quad \mathrm{SL}=$ Seedling Length; $\quad \mathrm{RL}=$ Root Length;

SHR = Shoot Height Reduction; $\quad$ VI = Vigor Index; $\quad$ FW = fresh weight;

RHR $=$ Root Height Reduction; $\quad$ R:S = Root Shoot Ratio; $\quad *=$ Significant

Table 4. Mean comparison for the effect of salt type and concentration to Camelina sativa seeds germinated in 11 days.

\begin{tabular}{|c|c|c|c|c|c|c|c|c|c|c|c|c|}
\hline $\begin{array}{l}\text { Conce- } \\
\text { ntration } \\
(\mathrm{g} / \mathrm{l})\end{array}$ & $\begin{array}{l}\text { Salt } \\
\text { type }\end{array}$ & $\begin{array}{l}G P \\
(\%)\end{array}$ & $S G$ & $R I R$ & GI & $\begin{array}{l}S L \\
(\mathrm{~cm})\end{array}$ & $\begin{array}{l}R L \\
(\mathrm{~cm})\end{array}$ & $R: S$ & $V I$ & $\overline{S H R}$ & RHR & $\begin{array}{l}F W \\
(g m)\end{array}$ \\
\hline $\mathbf{0}$ & & $96.25^{\mathrm{a}}$ & $49.46^{\mathrm{a}}$ & $0.00^{\mathrm{a}}$ & $55.69^{a}$ & $3.18^{\mathrm{a}}$ & $8.19^{\mathrm{a}}$ & $2.47^{\mathrm{a}}$ & 1106.42 & $0.00^{\mathrm{a}}$ & $0.00^{\mathrm{a}}$ & $0.39^{\mathrm{a}}$ \\
\hline \multirow[t]{2}{*}{1} & $\mathrm{NaCl}$ & $82.50^{\mathrm{b}}$ & $45.17^{b}$ & $14.28^{\mathrm{b}}$ & $49.98^{\mathrm{ab}}$ & $1.37^{\mathrm{b}}$ & $6.14^{\mathrm{ab}}$ & $4.94^{\mathrm{b}}$ & $625.22^{b}$ & $58.84^{\mathrm{b}}$ & $26.42^{\mathrm{b}}$ & $0.04^{\mathrm{b}}$ \\
\hline & $\mathrm{KCl}$ & $76.88^{b}$ & $42.25^{\mathrm{b}}$ & $20.21^{\mathrm{bc}}$ & $46.45^{\mathrm{bc}}$ & $1.97^{\mathrm{b}}$ & $5.65^{\mathrm{bc}}$ & $2.82^{\mathrm{a}}$ & $602.69^{b}$ & $45.09^{b}$ & $42.06^{c}$ & $0.03^{\mathrm{b}}$ \\
\hline \multirow[t]{2}{*}{2} & $\mathrm{NaCl}$ & $71.25^{\mathrm{c}}$ & $36.71^{b}$ & $25.83^{\mathrm{c}}$ & $41.46^{\mathrm{c}}$ & $1.02^{\mathrm{b}}$ & $3.49^{c}$ & $3.46^{\mathrm{a}}$ & $292.41^{\mathrm{c}}$ & $73.65^{\mathrm{cd}}$ & $57.02^{\mathrm{d}}$ & $0.02 b^{c}$ \\
\hline & $\mathrm{KCl}$ & $73.13^{\mathrm{c}}$ & $38.93^{b c}$ & $24.00 \mathrm{c}$ & $43.81^{\mathrm{c}}$ & $1.22^{\mathrm{b}}$ & $3.61^{\mathrm{c}}$ & $2.82^{\mathrm{a}}$ & $353.80^{c}$ & $62.48^{\mathrm{c}}$ & $55.07^{\mathrm{d}}$ & $0.02 b^{c}$ \\
\hline \multirow[t]{2}{*}{3} & $\mathrm{NaCl}$ & $70.00^{\mathrm{d}}$ & $36.02^{\mathrm{bc}}$ & $27.09^{\mathrm{cd}}$ & $41.66^{\mathrm{c}}$ & $0.60^{c}$ & $1.71^{\mathrm{d}}$ & $2.96^{\mathrm{a}}$ & $163.87^{\mathrm{d}}$ & $81.79^{\mathrm{de}}$ & $79.37^{\mathrm{e}}$ & $0.02 b^{c}$ \\
\hline & $\mathrm{KCl}$ & $66.25^{\mathrm{d}}$ & $34.72^{\mathrm{bc}}$ & $30.99^{\mathrm{d}}$ & $40.94^{c}$ & $0.44^{\mathrm{c}}$ & $1.72^{\mathrm{d}}$ & $4.35^{\mathrm{b}}$ & $141.25^{\mathrm{d}}$ & $86.65^{\mathrm{de}}$ & $79.0^{\mathrm{e}}$ & $0.01^{\mathrm{c}}$ \\
\hline \multirow[t]{2}{*}{4} & $\mathrm{NaCl}$ & $55.00^{\mathrm{e}}$ & $25.71^{\mathrm{d}}$ & $42.81^{\mathrm{e}}$ & $31.09^{\mathrm{d}}$ & $0.34^{\mathrm{c}}$ & $0.88^{\mathrm{e}}$ & $2.67^{\mathrm{a}}$ & $67.21^{\mathrm{e}}$ & $89.61^{\mathrm{e}}$ & $89.41^{\text {ef }}$ & $0.006^{\mathrm{d}}$ \\
\hline & $\mathrm{KCl}$ & $59.37^{\mathrm{e}}$ & $23.49^{\mathrm{d}}$ & $38.39^{\mathrm{e}}$ & $30.64^{\mathrm{d}}$ & $0.35^{\mathrm{c}}$ & $0.74^{\mathrm{e}}$ & $2.14^{\mathrm{a}}$ & $89.56^{\mathrm{e}}$ & $89.33^{\mathrm{e}}$ & $90.84^{\mathrm{f}}$ & $0.004^{\mathrm{d}}$ \\
\hline \multirow[t]{2}{*}{5} & $\mathrm{NaCl}$ & $21.87^{f}$ & $9.82^{\mathrm{e}}$ & $77.27^{f}$ & $12.56^{\mathrm{e}}$ & $0.31^{\mathrm{c}}$ & $0.55^{\mathrm{e}}$ & $1.19^{\mathrm{a}}$ & $43.24^{\mathrm{f}}$ & $90.63^{\text {ef }}$ & $93.17^{\mathrm{f}}$ & $0.002^{\mathrm{e}}$ \\
\hline & $\mathrm{KCl}$ & $4.37^{\mathrm{g}}$ & $1.220^{\mathrm{f}}$ & $95.50^{\mathrm{g}}$ & $2.69^{f}$ & $0.007^{\mathrm{d}}$ & $0.01^{\mathrm{f}}$ & $0.71^{\mathrm{c}}$ & $0.031^{\mathrm{g}}$ & $99.79^{\mathrm{f}}$ & $99.91^{\mathrm{f}}$ & $0.001^{\mathrm{e}}$ \\
\hline
\end{tabular}

Note:

*Means with the same letters in each column are not significantly different at 0.05 as per LSD test. $\mathrm{TG}(\%)=$ Total Germination Percentage; RIR = Relative Injury Rate; GI = Germination index; $\mathrm{SP} \quad=$ Speed of Germination; $\quad \mathrm{SL}=$ Seedling Length; $\quad \mathrm{RL}=$ Root Length; SHR = Shoot Height Reduction; $\quad$ R:S = Root Shoot Ratio; $\quad$ VI = Vigor Index; RHR = Root Height Reduction; $\quad$ FW = Fresh Weight $\quad *$ Significant. 


\subsection{Germination Index and Relative Injury Rate of $\mathrm{NaCl}$ and $\mathrm{KCl}$}

In this study germination index was decreased significantly with increasing $\mathrm{NaCl}$ and $\mathrm{KCl}$ concentrations (Table 2). The reduction gets stronger particularly at the higher level of salt concentrations $(5 \mathrm{~g} / \mathrm{L} \mathrm{NaCl}$ and $5 \mathrm{~g} / \mathrm{L} \mathrm{KCl})$ when compared to control. Maximum germination index of $C$. sativa was recorded as 55.68 at the control and as 48.2 at $1 \mathrm{~g} / \mathrm{L}$ compared to minimum recorded of 7.63 at $5 \mathrm{~g} / \mathrm{L}$ (Table 3). Relative injury rate of $\mathrm{NaCl}$ and $\mathrm{KCl}$ was calculated on the basis of germination percentage in control to the salinity treatments and it was found to be highest with increased salinity (Table 2). Even though a significantly $(\mathrm{P}<005)$ different was not observed in the relative injury rate of the salt types (Table 1). But, higher injury rate was shown in C. sativa seeds treated with $\mathrm{KCl}(34.85 \%)$ as compared to that of $\mathrm{NaCl}$ treated $(31.21 \%)$ (Table 4). In both salts $(\mathrm{NaCl}$ and $\mathrm{KCl})$ the relative injury rate was increased as the salt concentration increases from $1 \mathrm{~g} / \mathrm{L}(17.24 \%$ ) to $5 \mathrm{~g} / \mathrm{L}$ (86.39\%) (Table 3).

These results are similar with the findings of other researchers conducted in different crops at different corners of the world. The decline in the seedlings growth of various species as a result of salt stress was reported in different oilseeds such as Lady`s Fingers (Miryam et al., 2015), safflower (Give et al., 2014), sunflower (Ghazizade et al., 2012), brassica (Bybordi and Tabatabaei, 2009), rice (Morales et al., 2012) and Sweet Basil (Caliskan et al., 2017). Generally, increasing salinity causes a decrease in $C$. sativa germination parameters, speed of germination by 40.26 in $\mathrm{NaCl}$ and 48.24 in $\mathrm{KCl}$, total germination percentage by $74.38 \%$ in $\mathrm{NaCl}$ and $91.88 \%$ in $\mathrm{KCl}$, germination index by 43.12 in $\mathrm{NaCl}$ and 52.99 in $\mathrm{KCl}$, and increased its relative injury rate of $\mathrm{NaCl}$ and $\mathrm{KCl}$ by 77.27 and 95.5 respectively as compared to the control (Table 2). This might be due to the toxic effects of $\mathrm{Na}^{+}, \mathrm{K}^{+}$and $\mathrm{Cl}^{-}$in the process of germination (Morales et al., 2017). It alters the absorption of water by seeds due to lower osmotic potential of germination media, causes toxicity which changes the activity of enzymes of nucleic acid metabolism, changes protein metabolism and reduces the utilization of seed reserve food (Wu et al., 2015).

\subsection{Effect of Salinity on Early Seedling Growth of Camelina sativa}

The data in table 3 shown that $\mathrm{NaCl}$ and $\mathrm{KCl}$ salinity were significantly $(\mathrm{P}<0.05)$ affected all the seedling growth parameters of $C$. sativa. At the highest salt concentration, $5 \mathrm{~g} / \mathrm{L} \mathrm{NaCl}$ and $\mathrm{KCl}$ recorded the lowest averages of these characters compared with the control. Increasing salt concentrations from $0 \mathrm{~g} / \mathrm{L}$ to $5 \mathrm{~g} / \mathrm{L} \mathrm{NaCl}$ and $\mathrm{KCl}$ gradually decreased averages of seedling shoot length (Fig 1a) and root length (Fig 1b), vigor index (Fig 3a) and fresh weight ( Fig 4). Shoot 
height reduction (Fig 2a) and root height reduction (Fig $3 b$ ) were increased as the concentration of both salts raised from $0 \mathrm{~g} / \mathrm{L}$ to $5 \mathrm{~g} / \mathrm{L}$.



Figure 4. The Effect of salinity $(\mathrm{NaCl}$ and $\mathrm{KCl})$ seedling fresh weight of C. Sativa.

\subsection{The Effect of Salinity on Root and Shoot Length of Camelina Sativa}

The root and shoot length are considered to be important index of plant responses to salt stress. In present study, shoot and root length decreased with increasing stress intensity of salt stress (Table 3). Root elongation was more sensitive than shoot under the stresses on both salt types (Fig 3b). shoot and root lengths were reduced by more than $50 \%$ at lower $\mathrm{NaCl}$ and $\mathrm{KCl}$ salt stresses $(1 \mathrm{~g} / \mathrm{L}$ and $2 \mathrm{~g} / \mathrm{L})$ and more than $95 \%$ were inhibited at the highest salt $(5 \mathrm{~g} / \mathrm{L} / \mathrm{m})$ concentrations (Fig $2 \mathrm{a}$ and $2 \mathrm{~b}$ ).

Earlier studies have shown that $\mathrm{KCl}$ and $\mathrm{NaCl}$ treatment decreased shoot and root lengths of plants (Mori et al., 2011; Gebremedhn and Berhanu, 2013; Habibi and Abdoli, 2013; Give et al., 2014). In this study, the presence of $\mathrm{NaCl}$ and $\mathrm{KCl}$ reduced the shoot fresh and root lengths of $C$. sativa as compared to the control as a consequence of salt osmotic effects, that could reduce water availability and cellular pressure. During imbibitions, water entry occurs through aquaporins, which have reduced expression in the presence of salt (Morales et al., 2017). Similar results were also found in older seedlings of chick pea by Li. (2008); and Kandil et al. (2012). As the osmotic pressure decreases at the germination environment, water cannot carry most of the water soluble nutrition to the root in order to increase osmotic pressure of roots to get enough 
water (Radić et al., 2013). As a result, as the salinity level increases, the growth of shoot and root becomes slower and mostly the roots become dried after some days. This is probably because of the fact that high salinity may inhibit root and shoot elongation due to slowing down the water uptake by Dusty Miller (Radić et al., 2013). This result is also supported by the studies conducted on maize by Khodarahmpour et al. (2012); garden cress by Habibi and Abdoli (2013); wild soybean by Xue et al. (2014). They reported that salinity can rapidly inhibits root growth and then capacity of water uptake and essential mineral nutrition from soil also reduced.

\subsection{Vigor Index and Root Shoot Ratio (Length)}

Based on the analysis of variances, the salinity concentration of both salts $(\mathrm{NaCl}$ and $\mathrm{KCl})$ have significant $(\mathrm{P}<0.05)$ effect on vigor index (Table 1). Increasing of the two salinities causes a significant decrease $(\mathrm{P}<0.05)$ in $C$. sativa vigor index (Table 3 and Fig. 3a). This decrease was from 1106.42 at $0 \mathrm{~g} / \mathrm{L}$ to 21.63 at $5 \mathrm{~g} / \mathrm{L}$ (Table 3 ). However, the salinity effect of the salt types, $\mathrm{NaCl}$ and $\mathrm{KCl}$ doesn't have significant $(\mathrm{P}<0.05)$ differenceon the vigor index of C.sativa (Table 4).Analysis of variance indicated that salinity level of both salt types have significant effects on root shoot ratio (Table 1). Salinity of both salts $(\mathrm{NaCl}$ and $\mathrm{KCl})$ had a significant $(\mathrm{P}<0.05)$ effect on root to shoot ratio of $C$. sativa seed. It was decreased significantly with increasing salinity level from $0 \mathrm{~g} / \mathrm{L}(2.47)$ to $5 \mathrm{~g} / \mathrm{L}(0.96)$ (Table 3). But, a significant $(\mathrm{P}<0.05)$ difference was not observed on the effect of the salt types (Table 4) and the interaction of salinity leveland salt type on the root shoot ratio of $C$. sativa (Table 1). However, the effect is more pronounced in $C$. sativa seeds treated with $\mathrm{NaCl}$ in comparison with $C$. sativa seeds treated with $\mathrm{KCl}$ (Fig $3 \mathrm{~b}$ ).

Similar results were found by Akbari et al. (2015) working in corn seeds, foundhigher reduction in vigour index as salinity level increases.This may be relates with the significant decrement in seedling length and total germination percentage of the treated seeds (Miryam et al., 2015).Wu et al. (2015) resulted areduced of vigor index of sunflower seedlings with less root and shoot length at higher salinity level than the seedlings from lower salinity level. This study showed that salt stress inhibits root growth more than primary shoot growth of $C$. sativa. The decrement of R: S ratio with increasing salinity levelcould be due to the first exposition of the root to salinity (ionic effect) rapidly affected before the shoots (Arbaoui et al., 2015).

\subsection{Seedling Fresh Weights}

Seedling fresh weight was significantly affected $(\mathrm{P}<0.05)$ by salinity levels. The highest seedling fresh weight was obtained from $0 \mathrm{~g} / \mathrm{L}(0.392 \mathrm{~g})$ salinity level and the lowest seedling fresh weight 
was found at $5 \mathrm{~g} / \mathrm{L}(0.002 \mathrm{~g})$ (Table 3). Figure 5revealed that, seedling fresh weight significantly decreased as salinity level of both salts increased.

Different researchers found similar findings with theresults of the present investigation (Kusvuran et al., 2015; Morales et al., 2017).The reduction in biomass of C.sativa seedlings may be due to the osmotic and ionic stress effects of salinity that lowers the amount of water in the plant tissue (Adams et al., 2012). This increases stomatal resistance that results in closure of the stomata and hasan effect on plant growth. Stomatal size has already been shown to be a concern as it relates to gas exchange and low $\mathrm{CO}_{2}$ fixation (Kusvuran et al., 2015). It has been reported that the resistance to the diffusion of water vapor through a plant's stomata increases in saline soil (Wu et al., 2015). Although closing of stomata prevents water loss but, cannotfacilitate gas exchange with atmospheric carbon dioxide $\left(\mathrm{CO}_{2}\right)$ efficiently and resulted in net decrease in photosynthesis leading to a reduction in plant biomass and growth (Cokkizgin, 2012).

\section{CONCLUSIONS AND RECOMMENDATIONS}

\subsection{Conclusions}

The following conclusions were drawn based on the results of the present study

According to the results of this work, salt $(\mathrm{NaCl}$ and $\mathrm{KCl})$ stress reduces severely the speed of germination, germination percentage, germination index, shoot length, root length, vigor index, root shoot ratio and seedling fresh weight of the salt treated C.sativa seeds. Fresh weight of seedlings decreased as seedling length declined with increasing in salinity level particularly at highest levels of salt concentration $(5 \mathrm{~g} / \mathrm{L})$. Roots of C.sativa were affected more than shoot as evident from root/shoot ratio. Generally, the ability of C.sativa to germinate, seedling survives and overall performance was affected due to the effect of salinity.

\subsection{Recommendations}

Based on the results of this study the following recommendations are forwarded:

This study was conducted at laboratory condition and may provide some information but it may not show the actual germination and growth responses under field condition. Therefore, further study at filed conditions is required to confirm the results. The present study limited only on the effect of salinity on seed germination and early seedling growth of $C$. sativa; but, extended studies are needed to assess this effect up to flowering and yield production of this plant. Salinity might have disturbed the metabolic and physiological processes starting from the imbibition 
stage, as a result causes more delay in germination followed by increasing seed germination duration. Besides, the effect of salinity on of physiology, molecular and biochemical of $C$. sativa should be studied.

\section{ACKNOWLEDGMENTS}

We would like to acknowledge to Wachemo and Mekelle Universities for their financial and material provision.

\section{CONFLICT OF INTERESTS}

There is no any conflict of interests

\section{REFERENCE}

Adams, H.D., Luce, C.H., Breshears, D.D., Allen, C.D., Weiler, M., Hale, V.C., Smith, A.M.S \& Huxman, T.E. 2012. Ecohydrological consequences of drought- and infestation- triggered tree die-off: insights and hypotheses. Ecohydrology, 5: 145-159.

Akbari, M.M., Mobasser, H.R \& Ganjal, H.R. 2015. Influence of Salt Stress and Variety on some Characteristics of Corn. Biological Forum - An International Journal, 7: 441-445.

Al-Shehbaz, I. A., Beilstein, M. A \& Kellogg, E. A. 2006. Systematics and phylogeny of the Brassicaceae (Cruciferae): an overview. Plant Syst. Evolution, 259: 89-120.

Arbaoui, M., Yahia, N \& Belkhodja, M. 2015. Germination of the tomato (Lycopersicon esculentum Mill.) in response to salt stress combined with hormones. International Journal of Agronomy and Agricultural Research, 7: 14-24.

Ashraf, M \& Harris, P.J.C. 2004. Potential biochemical indicators of salinity tolerance in plants. Plant Science, 166: 3-16.

Berti, M., Gesch, R., Eynck, C., Anderson, J \& Cermak, S. 2016. Camelina uses, genetics, genomics, production, and management. Ind. Crop and Prod, 94: 690-710.

Bybordi, A \& Tabatabaei, J. 2009. Effect of salinity stress on germination and seedling properties in canola cultivars (Brassica napus L.). Notulae Botanicae Horti Agrobotanici Cluj-Napoca, 37: 71-76. 
Caliskan, O., Kurt, D., Temizel, K.E \& Odabas, M.S. 2017. Effect of Salt Stress and Irrigation Water on Growth and Development of Sweet Basil (Ocimumbasilicum L.). Open Agriculture, 2: 589-594.

Cokkizgin, A. 2012. Salinity stress in common bean (Phaseolus vulgaris L.) seed germination. Notulae Botanicae Horti Agrobotanici Cluj-Napoca, 40: 177-182.

Dönmez, E.O \& Belli, O. 2007. Urartian plant cultivation at Yoncatepe (Van), Eastern Turkey. Econ. Bot., 61: 290-298.

Eidhin, D.N \& O’Beirne, D. 2010. Oxidative stability of camelina oil in salad dressings, mayonnaises and during frying. Int. J. Food Science, 45: 444-452.

Fantaw, A. 2007. An overview of Salt-affected soils and their Management status in Ethiopia. Paper presented in the $3^{\text {rd }}$ International Workshop on Water Management project, Haramaya University, Ethiopia.doi:10.1094/PDIS-91-4-0467B[Article], [Google Scholar]

Francis, A \& Warwick, S. I. 2009. The biology of Canadian weeds. Camelina alyssum (Mill.) Thell; C. microcarpa Andrz. Ex DC; C. sativa (L.) Crantz. Can. J. Plant Science, 89: 791-810.

Frohlich, A \& Rice, B. 2005. Evaluation of Camelina sativa oil as a feedstock for biodiesel production. Ind. Crops Prod, 21: 25-31.

Gebremedhn Yohannes \& Berhanu Abraha. 2013. The role of seed priming in improving seed germination and seedling growth of maize (Zea mays L.) under salt stress at laboratory conditions. African Journal of Biotechnology, 12: 6484-6490.

Ghazizade, M., Golkar, P \& Salehinejad, F. 2012. Effect of salinity stress on germination and seedling characters in safflower Carthamustinctorius L. genotypes. Annals of Biological Research, 3: 114-118.

Give, H.S., Firoozi, M \& Ahmadzadeh, N. 2014. Investigation of seed germination and seedling characteristics of safflower variety under salt stress conditions. International Research Journal of Applied and Basic Sciences, 8: 2044 - 2049.

Habibi, A \& Abdoli, M. 2013. Influence of salicylic acid pre-treatment on germination, vigor and growth parameters of garden cress (Lepidiumsativum) seedlings under water potential loss at salinity stress. International Research Journal of Applied and Basic Sciences, 4: 1393-1399 
Hurtaud, C \& Peyraud, J.L. 2007. Effects of feeding Camelina (seeds or meal) on milk fatty acid composition and butter spreadability. Journal Dairy Science, 90: 5134-5145.

Hussain, K., Ashraf, M \& Ashraf, M.Y. 2008. Relationship between growth and ion relation in pearl millet (Pennisetumglaucum (L.) R. Br.) at different growth stages under salt stress. African Journal of Plant Science, 2: 23-27.

Islam, M.M \& Karim, M.A. 2010. Evaluation of Rice (Oryza sativa L.) genotypes at germination and early seedling stage for their tolerance to salinity. The Agriculturists, a Scientific Journal of Krishi Foundation, 8: 57-65.

Kandil, A.A., Sharief, A.E \& Ahmed, S.R.H. 2012. Germination and Seedling Growth of Some Chickpea Cultivars (Cicerarietinum L.) under salinity stress. Journal of Basic and Applied Sciences, 8: 561-571.

Karvonen, H.M., Aro, A., Tapola, N.S., Salminen, I., Uusitupa, M.I \& Sarkkinen, E.S. 2002. Effect of alpha-linolenic acid-rich Camelina sativa oil on serum fatty acid composition and serum lipids in hypercholesterolemic subjects. Metabolism, 51:1253-1260.

Khan, M.J., Rashid, H \& Ali, R. 1999. Inter-varietal variability in wheat grown under saline conditions. Pakistan Journal of Biological Science, 2: 693-696.

Khodarahmpour, Z., Ifar, M \& Motamedi, M. 2012. Effects of NaCl salinity on maize (Zea mays L.) at germination and early seedling stage. African Journal of Biotechnology, 11: 298304.

Kusvuran, A., Nazli, R.I \& Kusvuran, S. 2015. The Effects of Salinity on Seed Germination in Perennial Ryegrass (Loliumperenne L.) Varieties. Journal of Agricultural and Natural Sciences, 2: 78-84

Larsson, M. 2013. Cultivation and processing of Linumusitatissimum and Camelina sativa in southern Scandinavia during the Roman Iron Age. Veget. Hist. Archaeobotony, 22: 509520.

Li, Y. 2008. Effect of salt stress on seed germination and seedling growth of three Salinity plants. Pakistan Journal of Biological Science, 11: 1268-1272.

Lu, C \& Kang, J. 2008. Generation of transgenic plants of a potential oilseed crop Camelina sativa by Agrobacterium mediated transformation. Plant Cell Rep., 27: 273-278.

Miryam, O. Moulay, B \& Narimane, Z. 2015. Effect of salinity on seed germination of Abelmoschus esculentus. African Journal of Agricultural Research, 10: 2014-2019. 
Morales, S.G., Trejo-Téllez, L.I., Merino, F.C.G., Caldana, C., Espinosa-Victoria, D \& Cabrera, B.E. 2012. Growth, photosynthetic activity, and potassium and sodium concentration in rice plants under salt stress. Journal of Agronomy, 34: 317-324.

Morales, D., Potlakayala, S., Soliman, M., Daramola, J., Weeden, H., Jones, A., Kovak, E., Lowry, E., Patel, P., Puthiyaparambil, J., Goldman, S \& Sairam Rudrabhatla, S. 2017. Effect of Biochemical and Physiological Response to Salt Stress in Camelina sativa. Communications in Soil Science and Plant Analysis, 48: 716-729.

Mori, M., Di-Mola I \& Quaglietta-Chiaranda, F. 2011. Salt stress and transplant time in snap bean: growth and productive behavior. International Journal of Plant Production, 5: 4963.

Moser, B.R \& Vaughn, S.F. 2010. Evaluation of alkyl esters from Camelina sativa oil as biodiesel and as blend components in ultra-low-sulfur diesel fuel. Bioresour. Technology, 101: 646-653.

Ni Eidhin, D., Burke, J., Lynch, B \& O’Beirne, D. 2003. Effects of dietary supplementation with camelina oil on porcine blood lipids. Journal of Food Science, 68: 671-679.

Panuccio, M.R., Jacobsen, S.E., Akhtar, S.S \& Muscolo A. 2014. Effect of saline water on seed germination and early seedling growth of the halophyte quinoa. AoB Plants, 6(pii): plu047.

Radić, S., Štefanić, P.P., Lepeduš, H., Roje, V \& Pevalek-Kozlina, B. 2013. Salt tolerance of Centaurearagusina (L) is associated with efficient osmotic adjustment and increased antioxidative capacity. Environmental and Experimental Botany, 87: 39-48.

Roy, S.J., Negrão, S \& Tester, M. 2014. Salt resistant crop plants. Current Opinion in Biotechnology, 26: 115-124.

Sokolinska, D.C., Majcher, M., Pikul, J., Bielinska, S., Czauderna, M \& Wojtowski, J. 2011. The effect of Camelina sativa cake diet supplementation on sensory and volatile profiles of ewe's milk. African Journal of Biotechnology, 10: 7245-7252

Tamirie Hawando. 1994. Desertification in Ethiopian highlands. Rala Report no. 200, Norwegian Church AID, P.O. Box. 101351, Regional Senior Consultant on Environment and Natural Resource Management, Addis Ababa, Ethiopia. 
Waraich, E.A., Ahmed, Z., Ahmad, R., Ashraf, M.I., Naeem, M.S \& Rengel, Z. 2013. 'Camelina sativa', a climate proof crop, has high nutritive value and multiple-uses: A review. Australian Journal of Crop Science, 7: 1551-1559.

Wu, G.Q., Jiao, Q \& Shui, Q.Z. 2015. Effect of salinity on seed germination, seedling growth, and inorganic and organic solutes accumulation in sunflower (Helianthus annuus L.). Plant Soil Environment, 61: 220-226.

Xue, Z., Zhao, S., Gao H \& Sun S. 2014. The salt resistance of wild soybean (Glycine soja Sieb.et Zucc. ZYD 03262) under $\mathrm{NaCl}$ stress is mainly determined by $\mathrm{Na}$ - distribution in the plant. Acta Physiologiae Plantarum, 36: 61-70 (DOI: 10.1007/s11738-013-1386-7).

Yang, J., Caldwell, C., Corscadden, K., He, Q.S \& Li, J. 2016. An evaluation of biodiesel production from Camelina sativa grown in Nova Scotia. Industrial Crops and Products, 81: $162-168$.

Zhang, J.L \& Shi, H.Z. 2013. Physiological and molecular mechanisms of plant salt tolerance. Photosynthesis Research, 115: 1-22. 